
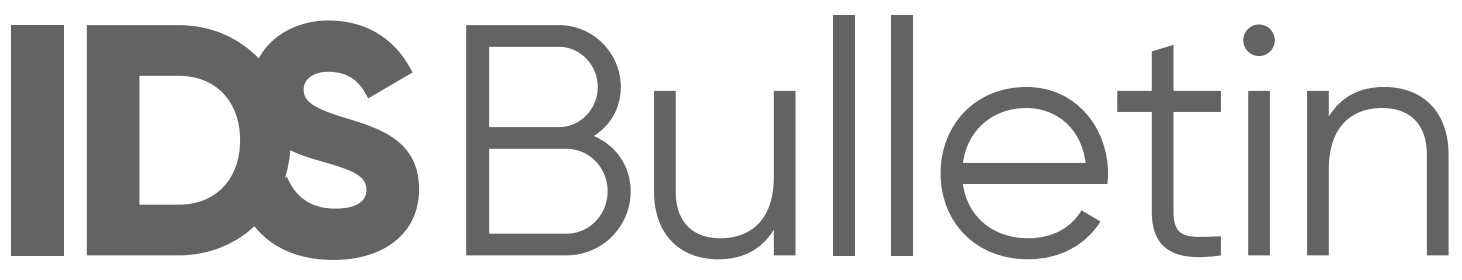

Transforming Development Knowledge

Volume 51 | Number 2 | September 2020

\title{
COLLECTIVE ACTION FOR ACCOUNTABILITY ON SEXUAL HARASSMENT: GLOBAL PERSPECTIVES
}

Editors Mariz Tadros and Jenny Edwards

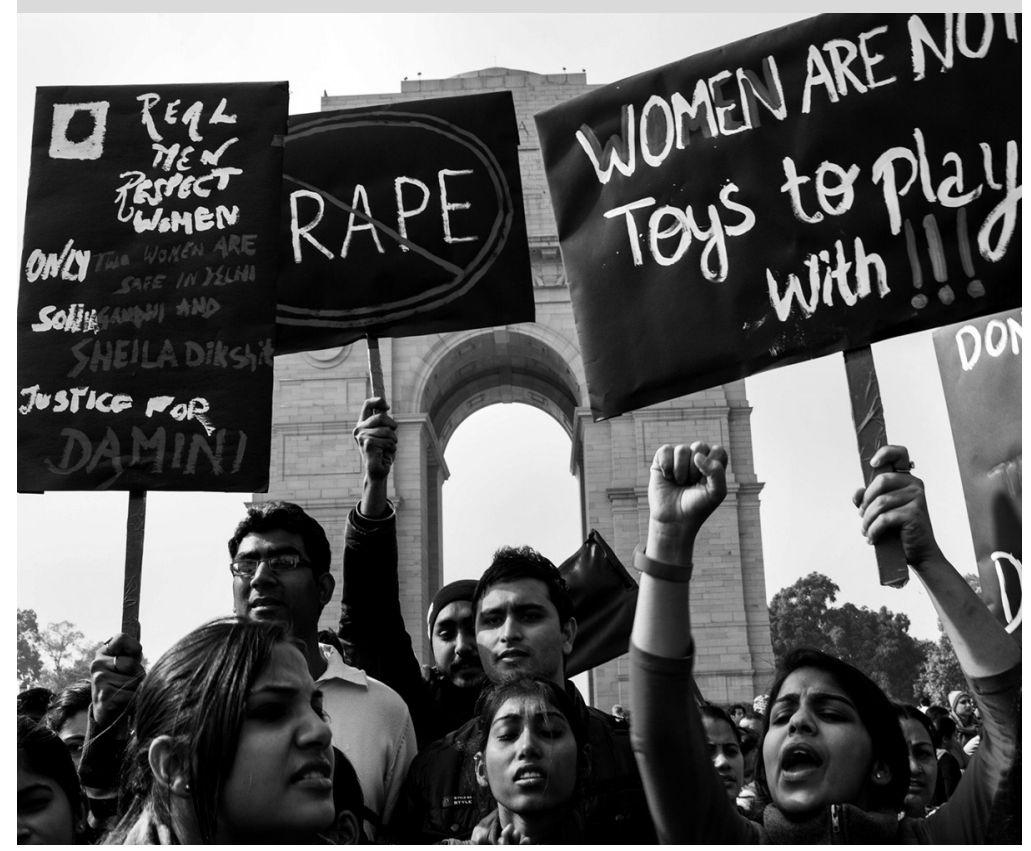


Notes on Contributors

Collective Struggles Against Sexual Harassment: What We Have Learnt About Pathways to Accountability and their Outcomes Mariz Tadros and Jenny Edwards

Fighting Sexual Harassment on Campus: How Local Contexts of Different Universities Affect the Dynamics and Outcome of these Efforts Amal Hamada, Ahmed Kheir, Enas Hamdy and Heba Youssif

Women Politicians Navigating the 'Hostile Environment' in Pakistan Ayesha Khan, Zonia Yousuf and Sana Naqvi

'Me Too' and the 'List' - Power Dynamics, Shame, and Accountability in Indian Academia

Adrija Dey

Multilevel Responses to Sexual Violence in Schools in West Africa

Jordan J. Steiner and Anne M. Spear

Uniting Against the Tides: Filipino 'Shefarers' Organising Against

Sexual Harassment

Lucia Tangi

Disruption and Design: Crowdmapping Young Women's Experience in Cities Sophie Tanner, Nicole Kalms, Hayley Cull, Gill Matthewson and Anthony Aisenberg

Collective Silence and Accountability for Sexual Harassment in Lebanon Menaal Munshey

Accountability with Teeth

Maha El Said

Glossary 


\title{
Collective Silence and Accountability for Sexual Harassment in Lebanon
}

\author{
Menaal Munshey ${ }^{1}$
}

\begin{abstract}
This article aims to analyse law and policy on sexual harassment in Lebanon, particularly how meaningful change can be achieved for women living there who face increased vulnerability due to their status as refugees and migrant domestic workers. Drawing on qualitative methods and documentary analysis, the article argues that sexual harassment legislation and a multisectoral change in attitudes is required for sexual harassment accountability to become a reality in Lebanon. While acknowledging Lebanese civil society's significant efforts on collectively pushing legislation and awareness-building, predating the global \#MeToo movement, increased efforts must be made on the prevention side, particularly for isolated, marginalised groups such as refugees and migrant domestic workers.
\end{abstract}

Keywords Lebanon, sexual harassment, gender-based violence, awareness, civil society, accountability, gender equality, refugees, Syria, Palestine.

\section{Introduction}

This article aims to analyse law and policy on sexual harassment in Lebanon, particularly how meaningful change can be achieved for women who face increased vulnerability due to their status as refugees and migrant domestic workers (MDWs) in Lebanon.

The article draws on qualitative methods and documentary analysis. Thematic analysis was used through (1) expert interviews conducted specifically for this article in September 2018, and (2) the author's recordings of a policy dialogue on sexual harassment bringing together key stakeholders organised by the Issam Fares Institute at the American University of Beirut (AUB IFI) in March 2018. ${ }^{2}$ In addition, documentary analysis involved primary sources such as draft legislation and secondary sources such as previous literature and newspaper articles. The author's understanding is shaped by her contextual field-based knowledge on the broader subject of gender-based violence in Lebanon. 
Table 1 Sexual harassment against women in public - male respondents

\begin{tabular}{|c|c|c|c|c|}
\hline & \multicolumn{3}{|c|}{$\begin{array}{l}\text { Percentage of men who have ever committed } \\
\text { specific acts of sexual harassment }\end{array}$} & \multirow{2}{*}{$\begin{array}{l}\text { Percentage of men } \\
\text { who have committed } \\
\text { specific acts of } \\
\text { harassment in the } \\
\text { past three months }\end{array}$} \\
\hline & Once & More than once & At least once* & \\
\hline Ogling ${ }^{* *}$ & 2.0 & 23.6 & 25.6 & 20.1 \\
\hline Catcalls or sexual comments & 3.5 & 11.3 & 14.9 & 11.3 \\
\hline Stalking or following & 2.2 & 2.3 & 4.5 & 2.8 \\
\hline $\begin{array}{l}\text { Online harassment such as } \\
\text { sending obscene photos or } \\
\text { messages }\end{array}$ & 2.1 & 1.0 & 3.1 & 1.1 \\
\hline $\begin{array}{l}\text { Touching a woman on intimate } \\
\text { parts of her body when she } \\
\text { didn't want you to }\end{array}$ & 0.8 & 0.4 & 1.1 & 0.3 \\
\hline Exposing private parts & 0.4 & 0.5 & 0.9 & 0.3 \\
\hline $\begin{array}{l}\text { Forcing a woman or girl to have } \\
\text { sex }\end{array}$ & 1.0 & 1.0 & 1.9 & 0.5 \\
\hline $\begin{array}{l}\text { Any of the above-mentioned } \\
\text { acts of harassment }\end{array}$ & & & 31.1 & 24.2 \\
\hline Number of men respondents & & & 1,050 & \\
\hline
\end{tabular}

Notes * 'At least once' is the sum of 'once' and 'more than once'; ** Statistically more Syrians than Lebanese perpetrated the sexual harassment.

Source UN Women, Promundo and CRD (2016: 92).

Lebanese civil society's collective push for legislation and awareness-building on the subject of sexual harassment is formidable. This article argues that for sexual harassment law and policy to take shape in Lebanon, increased efforts must be made on the prevention side, particularly for isolated, marginalised groups such as refugees and MDWs. These groups must be brought within the legal system through changes to the existing labour code and trust-building measures with state institutions. Previous domestic violence legislation enacted in 2014 provides an example of the power and pitfalls of gender-based violence legislation in Lebanon. The article therefore argues that sexual harassment legislation and a multisectoral change in attitudes is required for sexual harassment accountability to become a reality in Lebanon.

\section{Sexual harassment in Lebanon}

There is a lack of data on incidents of sexual harassment and attitudes towards sexual harassment in Lebanon. The International Men and Gender Equality Survey (IMAGES), as shown in Tables 1, 2 and 3, revealed that two-thirds of women have experienced sexual harassment in public places including 
Table 2 Percentage of women who have experienced specific acts of sexual harassment by men in public spaces

Percentage of women who have ever experienced specific acts of sexual harassment

\section{Once}

More than once
At least once*
Percentage of women who have experienced acts of sexual harassment in the past three months

\begin{tabular}{|c|c|c|c|c|}
\hline Ogling ${ }^{* *}$ & 7.3 & 38.5 & 45.8 & 38.6 \\
\hline Catcalls or sexual comments & 9.2 & 42.3 & 51.4 & 43.2 \\
\hline Stalking or following & 9.1 & 16.5 & 25.6 & 18.3 \\
\hline $\begin{array}{l}\text { Online harassment such as } \\
\text { sending obscene photos or } \\
\text { messages }\end{array}$ & 7.7 & 6.1 & 13.8 & 7.1 \\
\hline
\end{tabular}

Being touched on intimate 1.3

$1.1 \quad 2.4$

0.2

parts of your body when you

didn't want it

\begin{tabular}{lllll}
\hline Exposure of private parts & 3.6 & 2.0 & 5.6 & 2.1 \\
\hline Being forced to have sex & 2.6 & 0.5 & 3.1 & 0.4 \\
\hline
\end{tabular}

Any of the above-mentioned

57.0

acts of harassment

Number of women respondents

1,136

Notes * 'At least once' is the sum of 'once' and 'more than once'; ** Statistically fewer Syrians than Lebanese experienced the sexual harassment.

Source UN Women, Promundo and CRD (2016: 93).

Table 3 Participants that have perpetrated or experienced any act of sexual harassment or violence in public spaces

\begin{tabular}{|c|c|c|c|c|c|c|c|c|}
\hline & \multicolumn{4}{|c|}{ Lebanese } & \multicolumn{4}{|c|}{ Syrians } \\
\hline & \multicolumn{2}{|c|}{ Men } & \multicolumn{2}{|c|}{ Women } & \multicolumn{2}{|c|}{ Men } & \multicolumn{2}{|c|}{ Women } \\
\hline & $\%$ & $\mathbf{N}$ & $\%$ & $\mathbf{N}$ & $\%$ & $\mathbf{N}$ & $\%$ & $\mathbf{N}$ \\
\hline $\begin{array}{l}\text { Sexual harassment in a public } \\
\text { space ever }\end{array}$ & 29.7 & 239 & 60.6 & 513 & 37.0 & 85 & 47.3 & 121 \\
\hline $\begin{array}{l}\text { Sexual harassment in a public } \\
\text { space in the last three months }\end{array}$ & 22.3 & 180 & 52.1 & 441 & 30.9 & 71 & 43.8 & 112 \\
\hline
\end{tabular}

Source UN Women, Promundo and CRD (2016: 151). 
Figure 1 Reasons for sexual harassment

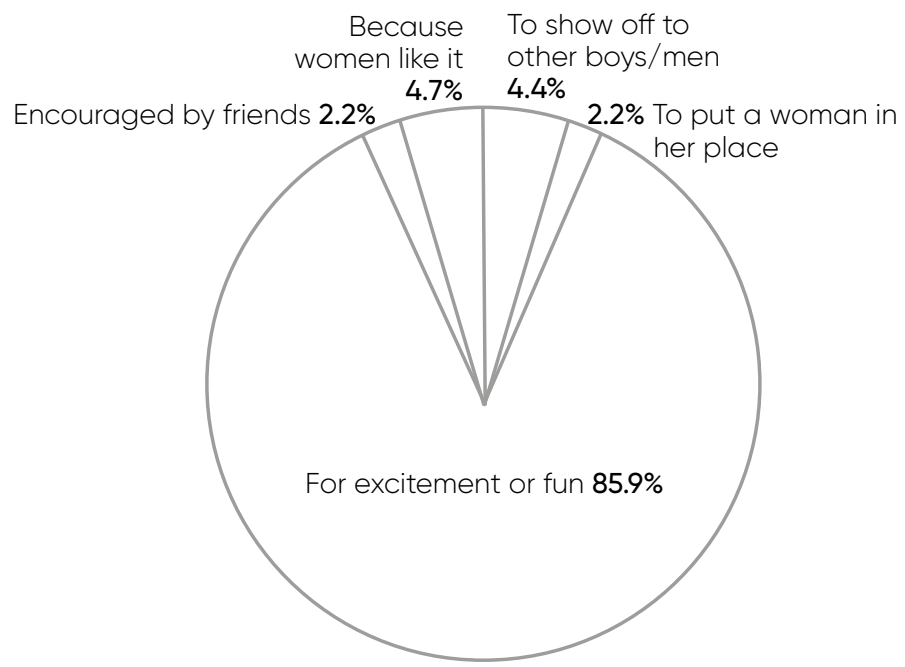

Source (c) UN Women, Promundo and CRD (2016: 94), reproduced with permission.

catcalls, sexual comments, or ogling (UN Women, Promundo and CRD 2016).

A recent study exploring public attitudes towards sexual harassment found that people hesitate to use the term when talking about their own experiences or experiences of those around them (Hassan, El Mir and El Rahi 2017). Men accepted being labelled as 'harassers' only when explicit sexual terminology was used. Women only call it verbal sexual harassment if loaded with explicit sexual terms, even though they report feeling humiliated, bothered, and insecure from comments that are not explicitly sexual (ibid.). In all interactions in public spaces, male desire outweighs women's feelings of discomfort and insecurity (ibid.). There is also a sense of 'othering' the problem: women blame Syrians for the harassment of women, even though the majority of the sample of Lebanese men living in Beirut admitted to engaging in sexually harassing behaviour.

An exploratory workplace study found that sexual harassment is largely recognised as physical interference, sexual favours, and exposing sexual material, and less so as sexual jokes and prolonged staring (Hejase 2015). In the study, 8 per cent (12 per cent of men and 16 per cent of women) reported being sexually harassed. Only 7 per cent had taken action; of the majority who had not taken action, this was reportedly due to fear of not being taken seriously, fear of not being promoted, fear of receiving a warning and it being kept on record, fear of being fired from their job, and out of shame (only females) (ibid.). 


\begin{tabular}{|c|c|c|}
\hline & Men & Women \\
\hline $\begin{array}{l}\text { Women who dress provocatively deserve to be } \\
\text { harassed }\end{array}$ & $56.5^{*}$ & $29.2^{*}$ \\
\hline $\begin{array}{l}\text { Women who are in public places at night are } \\
\text { asking to be harassed }\end{array}$ & 39.3 & $17.6^{*}$ \\
\hline A woman who is out alone is asking to be harassed & 27.7 & $9.2^{*}$ \\
\hline A woman likes the attention when men harass them & $51.4^{*}$ & $13.0^{*}$ \\
\hline
\end{tabular}

Media reports suggest that women who have experienced sexual harassment on public transportation testify to having to endure it on a daily basis, without the ability for recourse to justice due to a justice system that does not record such complaints against a stranger (Janoubia 2013). One article quotes a source from local Internal Security Forces (ISF) asserting that the reporting of such incidents is a rarity, with only one instance per year (Saida Online 2014).

A survey conducted with 1,000 people in Lebanon found that one in four women in the country is a victim of sexual harassment (LBCl Lebanon 2017). The survey suggests that 24 per cent of victims report the assault to the police. According to the ISF, at least 13 women per month reported sexual assaults from January to November 2017 (ibid.).

Based on limited previous literature (e.g. Hassan et al. 2017; Hejase 2015), it is clear that there is a general absence of specific grievance procedures and sanctions for sexual harassment. In addition, on the prevention side, there are a lack of antiharassment activities and education programmes, whether it be within organisations or aimed at the general public.

\section{Sexual harassment in refugee communities}

Sexual harassment incidents and the lack of remedies contribute to further marginalising vulnerable groups in profound and multiple ways. An exploratory study conducted in a Palestinian camp in Lebanon, Burj Barajneh, ${ }^{3}$ indicates that women and children are the most vulnerable to physical sexual harassment (Khalidi 2015). The study showed that sexual harassment incidents were most frequent in the daytime/afternoon, in alley ways (ibid.). This causes a feeling of insecurity for women in moving around most of the neighbourhoods, including their own, within the camp. Palestinian camps are home to Palestinian and Syrian refugees in Lebanon, and are among the most disadvantaged neighbourhoods in the country, with a general lack of adequate 
basic services and pre-existing issues of legality, housing, and social integration (Munshey 2018a). Young girls living in the Palestinian camps and the Bekaa Valley complain about verbal and physical sexual harassment (Charles and Denman 2013). This causes women to alter their behaviour, shrink from public space, and self-police. Citing fear as a reason, parents often do not permit their daughters to leave the house (ibid.). This results in the disempowerment of women who are already disadvantaged due to their refugee status.

Amnesty International's study of 77 Syrian refugee women living in different areas of Lebanon found that almost all the women were constantly harassed in public - by neighbours, bus and taxi drivers, strangers, ISF personnel, and government employees (Amnesty International 2016). One woman said:

Harassment [of refugee women] is a very big problem in Lebanon, whether I'm single or married, I'm always harassed. It's why we're afraid for our children. I have a daughter who is 16 and I'm afraid to send her even to the closest shop. It's the suffering of all Syrians. (Amnesty International 2016: 45)

Human Rights Watch has also found that Syrian refugee women have been sexually harassed by employers, landlords, local faithbased aid distributors, and community members in Beirut, the Bekaa, and North and South Lebanon (Human Rights Watch 2013).

Refugee women are at risk of sexual harassment in public places and the workplace, which contributes to a lack of economic empowerment (Munshey 2018a). One refugee told Human Rights Watch (2013) that she suffered sexual harassment at nine of the ten households where she had worked. Highlighting a lack of trust, she said she did not report the incidents to Lebanese authorities or the United Nations because she did not believe they would help her as a refugee. As a result, she has stopped working and is now depending on charity to survive. Another woman told Human Rights Watch that her employer at a clothing store grabbed her from behind, touched her breasts, and pressured her to have sex. This happened at multiple workplaces, after which she became depressed and stopped working. She had reported one of the incidents to a United Nations High Commissioner for Refugees (UNHCR) caseworker, who offered comfort but said there was nothing more she could do. She could not report the incidents to local authorities because she and her relatives lack valid residency permits. This is a common reason for the lack of reporting, remedies, and accountability for refugees (ibid.). There have also been reports of sexual harassment being faced by refugees who turned to local faith-based aid organisations (ibid.). When 'safe' institutions misuse their power in this way, fear leaves refugee women with no place to turn to in cases of sexual harassment. 


\section{Migrant domestic workers' experience}

Every domestic worker has experiences with sexual harassment and sexual violence living in Lebanon, to different degrees. (Interview with a Migrant Community Centre (MCC) representative, September 2018)

An estimated 200,000 documented MDWs live in Lebanon. MDWs regularly endure sexual harassment in their place of employment (Hall 2018a). For example, 11 per cent of Sri Lankan housemaids reported being sexually harassed (Moukarbel 2009). The overwhelming majority of cases go unreported due to the fear of repercussions. If an MDW leaves their employer, they are breaking the law the moment they run away (Hall 2018a); this means they risk detention and deportation if they seek official support. For example, in July 2018, a Kenyan woman was brutally assaulted in a racially motivated mob attack, caught on CCTV, and deported before her case was resolved (Hall 2018b). Such institutionalised racism in Lebanon continues largely unchecked, with grave consequences (De Stone and Suber 2018). According to the General Security's official figures, the dead bodies of MDWs were repatriated to their home countries at a rate of two per week between January 2016 and April 2017 (Hall 2018b).

Due to the Kafala sponsorship system, an MDW's legal status in Lebanon is tied to their employer. The Kafala system was introduced in Lebanon in 1991 at the end of the Lebanese civil war. According to the system, migrant workers are explicitly excluded from all existing labour laws in Lebanon (Human Rights Watch 2010). Currently, standard protections of the labour law do not apply to MDWs and there is not much impetus for change at an institutional level:

On the national level, there has not been any kind of change or any real will for change, which is very disappointing but also expected when it comes to Lebanese politics and how the system functions in Lebanon. Especially that there is a big reliance on the labour done by MDWs and others that are in the same care labour category (Category 4). So doing changes in that would entail doing a more comprehensive strategy and economic policy for the country that takes into consideration domestic work and care labour as a valuable and paid labour that we need in the country. They are seen as people who are doing work that isn't really necessary or isn't really important, whereas without that work people wouldn't really be able to do other forms of work. (Interview with an MCC representative, September 2018)

An MDW's only legal protection is a standard contract, developed in 2009 by the Lebanese Ministry of Labour, in cooperation with the Office of the High Commissioner for Human Rights (OHCHR) and the International Labour Organization (ILO), which outlines basic rights such as monthly salary payments, and the maximum 
number of daily working hours (OHCHR 2009). ${ }^{4}$ The contract does not address salient issues ${ }^{5}$ such as withholding passports and being locked in employers' houses, and is only offered in Arabic, which most MDWs cannot understand.

According to Article 17, a domestic worker can break the employment contract 'if the First Party (employer) or a family member of his/hers or any resident in his/her house beats, assaults, sexually abuses or harasses the Second Party (MDW), after such has been established through medical reports given by a forensic physician and investigation records provided by the Judicial Police or the Ministry of Labour' (ILO 2010: 4). Most domestic workers who are victims of violence or sexual harassment are isolated and rarely have timely access to a forensic doctor or the police due to a lack of requisite knowledge or resources. In addition, the contract does not allow a domestic worker to break the contract in the event of other types of mistreatment by her employer (ILO 2010). In contrast, Article 16 allows an employer wide autonomy to break the contract; this exemplifies the unequal Kafala system (Human Rights Watch 2010). Without reform of the Kafala system, it is unlikely that MDWs will be able to benefit from sexual harassment legislation. Yet reform alone would not mean the end to bad practices and attitudes, as these discriminatory, abusive practices have become internalised (El Helou 2015).

In 2010, the Minister of Labour announced a new hotline to receive complaints from MDWs and other workers (Human Rights Watch 2010). In addition, the Directorate General of General Security has a helpline where workers who have been subjected to physical or emotional abuse or sexual harassment can call in. However, they have to do so within 48 hours of the incident (ILO 2012). The success of these has not yet been measured. Even if they do complain, however, MDWs often face official inaction on the part of police and judicial authorities. For the most part, MDWs face a lengthy legal system without either adequate legal representation or translation (Human Rights Watch 2010). Although thus far the judicial system has remained largely inaccessible and unresponsive, it is the judiciary that has both the potential and obligation to play an important role in protecting the basic rights of MDWs.

Talking about sexual harassment accountability, an MCC representative said:

It really depends on if the MDW can prove it legally [...] the contract can be broken in cases of sexual harassment or physical violence. It should be proven in the court. She should have evidence. Either that she should record it via camera or audio or have physical marks that are assessed by a doctor and upheld in the court. So there are mechanisms that happen after things escalate to a level that the hurt is very visible and very acknowledgeable by the court. In reality, MDWs do not have the privilege of documentation. (Interview, September 2018) 
The multiple exclusions of migrant workers along class, gender, and racial lines, associated with an absence of legal protection, is propitious for their exploitation in Lebanon (ILO 2010). The UN Special Rapporteur has urged Lebanese authorities to ensure that domestic workers obtain legal protection and have prompt and immediate access to remedies and justice, and that employers are aware of their obligations when recruiting domestic workers (OHCHR 2011). Without this, a culture of silence persists, and systematic abuse is endemic. Within this restrictive environment, MDW movements have emerged to provide support and solidarity.

\section{Migrant domestic worker movements}

'[Sexual harassment] has always been part of campaigns for better labour laws and women's rights, so it's inseparable from them', said an MCC representative in an interview with the author in September 2018. In 2016, a group of female domestic workers formed the Alliance of Migrant Domestic Workers, with the aim of representing and building their own narrative (De Stone and Suber 2018). These activists use their only day off a week to create safe spaces for each other under significant environmental constraints: 'We cannot be aggressive. We cannot confront authorities directly or else we will always be the ones to lose' (ibid.).

Throughout the years, there has been a growing number of groups that are self-led by MDWs. Like we see in the last three years, less dependency on NGOs [non-governmental organisations] and more groups trying to help each other and trying to form their advocacy and also their community work so that's a great positive change because they're the ones who are more aware of their needs and know what are the better strategies that can really help themselves in similar situations. (Interview with an MCC representative, September 2018)

Increasingly, MDWs turn to a limited underground network for support (Hall 2018a). For example, the Anti-Racism Movement (ARM) was launched in 2010 by young Lebanese feminist activists in collaboration with MDWs and created three MCCs which provide safe spaces for MDWs to advance their rights (ARM-Lebanon 2018). These movements for collective action serve an important purpose:

At least at the very minimum it results in more allies, and more alliances between MDWs and local groups and local movements and activists who can then have a bigger change even within our local communities. When there are cases of abuse, before it was normalised and now there is more and more awareness that this is not acceptable. Even if people hear about it in their neighbourhoods, even if that level of small change is happening, that is still very important to happen, within a system that doesn't allow us very easily to change the bigger institution. (Interview with an MCC representative, September 2018) 
Migrant-led movements like these work towards countering sexual harassment and the delimitation of women's rights with bravery and localised knowledge. With legislative accountability being a distant dream, MDW movements often provide the only hope for women in abusive situations.

\section{Legislative accountability}

There is currently no specific sexual harassment legislation in Lebanon. In 2014, former parliamentarian Ghassan Moukheiber submitted a law proposing to criminalise sexual assault and racial discrimination. Due to protracted political deadlock, this was finally presented to Parliament as an 'urgent law proposal' in 2017. However, it was then detracted due to concerns raised by several MPs such as its potential misuse against employers (Namour 2017). Jean Ogasapian, the Minister of State for Women's Affairs, also expressed his interest in collaborating on the subject given his efforts to draft a similar law. A legislative committee was formed to consider both texts (Khneisser 2018). Moukheiber worked on partially amending the law in an attempt to combine it with Ogasapian's draft law (ibid.). Ogasapian's draft law was approved by the cabinet on 8 March 2017 and has remained awaiting approval from Parliament ever since (ibid.). Due to frequent political gridlock in Lebanon, it is difficult to determine when the law will come into force.

As Lebanon's draft laws remain in limbo, it is important to analyse the strengths and shortcomings of both laws. The discussion presented here centres around three themes: (1) definitions, (2) intersectionality, and (3) holistic change.

\subsection{Definitions}

The Lebanese Labour Law and Penal Code do not address sexual harassment, and there is no legal definition of sexual harassment. Moukheiber's law defines sexual harassment as an act that is 'shocking, insisting, or repetitive in any speech, action, or insinuation of a sexual or racist nature, directed to a person without consent, leading to aggression on dignity because of the nature, context, profession, pressure, or embarrassment caused' (Khneisser 2018).

Ogasapian's draft law proposes incorporating sexual harassment policies at the levels of the labour law and the penal law. The law proscribes sexual harassment at the level of the labour law as follows:

Any person, whether an employer or a wage earner, is prohibited from resorting to harassment, whether by means of a written confirmation or by any means of communication, pressure, or intimidation or issue orders aiming at receiving services of a sexual nature both for his own benefit or for the benefit of others. 
The draft law provides a second definition of sexual harassment in Article 535 of the penal law under 'public morals and ethics'. The definition is: 'To speak or to write, by any means of communication, by using anything that has a sexual connotation that compromises the honour and dignity of the victim, or if overlooked creates hostile or degrading situations' (Khneisser 2018).

During the roundtable policy dialogue on sexual harassment organised by the Issam Fares Institute at the American University of Beirut (AUB IFI) in March 2018, lawyer Manar Zeitar said, 'What is meant by protection? This is a trap. From 1943, protecting the community versus protecting the individual is given importance. In the laws there is no acknowledgement that sexual abuse is sexual violence. It is... not calling it what it is'. ${ }^{6}$

Judge Arlette Tabet reportedly noted that 'the law is formed to protect society and to protect society's morals before it protects individuals, and it is this that is the basis of injustice in many damning cases heard before the courts' (Dandan 2017). However, she hoped that judicial discretion would be used positively and to the benefit of victims (ibid.). The number of female judges in Lebanese civil courts has reached half the total number of judges, a huge step forward, which has the potential of making the civil justice system more gender equitable; and the judiciary may be the institutional hope for women seeking justice (Ghamroun 2015).

Sexual harassment is defined by the United Nations as

any unwelcome sexual advance, request for sexual favour, verbal or physical conduct or gesture of a sexual nature, or any other behaviour of a sexual nature that might reasonably be expected or be perceived to cause offence or humiliation to another (United Nations 2008: 1).

Premised on gender equality and fundamental rights, the European Union defines sexual harassment as 'where any form of unwanted verbal, non-verbal, or physical conduct of a sexual nature occurs, with the purpose or effect of violating the dignity of a person, in particular when creating an intimidating, hostile, degrading, humiliating or offensive environment' (European Union 2017: 3). The current definitions in Lebanon fall short of the international standard and instead shift emphasis away from harm faced by the individual and remain detached from the systemic nature of gender-based violence.

\subsection{Intersectionality}

Sexual harassment intersects with other forms of disadvantages, vulnerabilities, and marginalisation within society. The draft law presented by Moukheiber considers unequal relations such that they constitute an annulment of the 'consent' conditionality within sexual harassment. However, Ogasapian's draft law overlooks 
the inherent unequal power relations that predicate exploitative workplace relationships (Namour 2017).

The draft laws do not address systemic disadvantages that exclude marginalised and vulnerable groups, such as MDWs and refugees, from legal protection. Racial discrimination intersects with gender discrimination against these groups, and this should be legally recognised. Moukheiber's draft law took racial violence into account yet fell short of elaborating on it further and ensuring provisions for foreign domestic workers who fall outside the protection of the labour law (Khneisser 2018).

Charlotte Karam, Director of the Knowledge Is Power (KIP) Project, highlighted legal gaps at AUB IFl's roundtable which included the "relational aspects of power", "restrictive formulation of law and code of conduct", and failure to create "responsibilities which include (1) prevention obligations [...] (2) focus on redress mechanisms and processes, and (3) monitoring post-decision"'? In terms of remedies, both laws proposed resorting directly to criminal justice and the penal law to punish sexual harassment (Namour 2017). Given the intersectional nature of sexual harassment, these remedies are likely to be largely inaccessible for women. Based on the experience with the domestic violence legislation, which was promulgated in 2014, women face significant barriers in accessing justice including limited knowledge of their rights, limited financial means, and traditional patriarchal social norms which limit them from claiming their rights (Barakat 2018). The public's trust in Lebanese institutions is low, and this is deeper in refugee communities (Munshey 2018a). There is no adequate legal aid system. A gender perspective is almost systematically absent from the judicial process (Barakat 2018).

\subsection{Holistic change}

Both draft laws present a strong step forward. However, both have been criticised for not holistically addressing sexual harassment, as that requires amendments to the underlying Penal Code and Labour Law. This particularly affects MDWs and refugees.

Speaking of the difficulties for MDWs in demanding accountability within the current Kafala system, an MCC representative said:

From our experience in legal advocacy, these things take so much time, when they reach the Parliament they change a lot. So we are not having a lot of hope in them making change any time soon. How we approach the issue is that we can't have a sexual harassment law that targets MDWs without doing necessary changes to the Kafala system because then how can we really ensure that it is going to be applied or there will be safety mechanisms placed where MDWs are still locked in houses. And it goes hand in hand, it can't be separated. Even if they were not included [in the labour law], there can still be mechanisms that can help. But even in that 
case if we keep the legal framework the same it will not really do any real change when it comes to most people living under the system. (Interview, September 2018)

In the case of MDWs, without their full inclusion in the labour laws, they will not be able to benefit from sexual harassment - or other - legislation.

Talking about the importance of collective action, an MCC representative said:

When we are talking about people who experience harassment from people who are not their employers, whether they are Lebanese people or migrants or people who aren't their sponsors, there is nothing that can be done specially if they don't have papers. They cannot rely on any legal action or any legal mechanisms to remedy that. So this raises the question of the importance of community awareness or community action that in the absence of legal protection (it is important) to have communities that can defend themselves and can bring justice and safety to those involved. (Interview, September 2018)

This could be done through various awareness-raising public campaigns, such as Adventures of Salwa and \#MeshBasita, discussed in Section 7.

Lebanon's law on domestic violence which came into force in 2014 was an important first step in terms of gender-based violence legislation; however, the new law is problematic in its definitions and implementation (Munshey 2018b: 7). Learning from the experience of domestic violence legislation in Lebanon, the power of legislation is limited without associated social change and collective action demanding legislation and broader accountability.

\section{Collective action}

Collective action led by civil society in Lebanon has made significant achievements towards gender equality and combating gender-based violence such as the promulgation of domestic violence legislation in 2014. In recent years, sexual harassment has begun to receive increased attention within activism.

In 2011, a major public campaign aimed at sexual harassment was launched named 'The Adventures of Salwa'. 8 The video campaign featured an animated character, Salwa, who encounters sexual harassment in several settings and she uses her red bag to stay safe.? The intervention included an online reporting tool and geographical mapping of sexual harassment incidents across Lebanon. ${ }^{10}$ As part of the project, the Nasawiya (Feminist) Collective made up of civil society activists, lawyers, judges, and researchers drafted a comprehensive law on sexual harassment (Legal Agenda 2014). This draft law was later 
incorporated to some extent into the proposed law which is currently in front of the Lebanese Parliament (Nasr 2017).

In 2012, the AUB paved the way forward within the private sector by instituting an Equity Program with initiatives such as a code of conduct and an online reporting platform for incidents of sexual harassment and violence (AUB 2012). In 2013, Association Najdeh"11 launched a campaign with the slogan 'put your hand in my hand and not on it, you and I can stop harassment' to combat sexual harassment, targeting communities residing in Palestinian camps (WEE Portal 2013). That same year, the organisation Say No to Violence launched a campaign entitled 'Have You Seen Harassment?', advocating for effective laws and policies to combat sexual harassment (An-Nahar 2013).

Civil society organisations have made efforts to collect data under the larger umbrella of gender-based violence. In 2015, Lebanon Support's Civil Society Knowledge Centre in collaboration with KAFA (Enough - a feminist NGO) launched an interactive map of incidents of violence against women across Lebanon, which allows filtering by type of violence, including sexual harassment (Civil Society Knowledge Centre 2018). In 2016, a group of activists launched HarassTracker, an online platform to anonymously report sexual harassment. ${ }^{12}$ The aim of HarassTracker was to de-normalise the prevalence of sexual harassment (WEE Portal 2017). Data show that police and security forces are themselves the harassers in many cases, and that women do not trust them to protect them in cases of harassment (Hassan et al. 2017). This lack of trust is heightened in the case of refugees and MDWs, who are effectively unable to demand accountability from duty bearers who are unaccountable to them.

In August 2017, prior to the \#MeToo movement in the West, \#MeshBasita or 'It's not OK' was launched on social media in Lebanon. Launched by the KIP Project at AUB's Business School, in partnership with the Minister of State for Women's Affairs, \#MeshBasita was designed to raise awareness of what constitutes sexual harassment among the general public and build pressure on lawmakers to legislate on sexual harassment (McKernan 2017). The campaign highlighted the many forms of harassment that women face every day. ${ }^{13}$ As the Director of the KIP Project said:

That was part of the success. People were talking about it and we were involving them in developing messaging and what should we do here, etc. It just spread. It was coming from very local dialogue with these champions that are in their own disciplines or in their own stakeholder groups whether in business (or other industries). (Interview, September 2018)

However, the KIP Project did not originate with a focus on sexual harassment; rather, this came out of the project's initial research and activities: 
We realised sexual harassment was everywhere, whether we were talking about economic empowerment or health and wellbeing or GBV [gender-based violence] in the form of harassment and more extreme [...] it was everywhere. So that's why we decided to focus on sexual harassment in year two [of the project]. (Interview with Director of the KIP Project, September 2018)

Reflecting on the experience of the KIP Project, the Director said that a number of diverse stakeholders were involved in the project:

KIP garnered a lot of positive support. There was very little backlash. The government reached out to KIP to get involved in the conversation, there was the establishment of the new Ministry [of State for Women's Affairs]. We had been reached out to by gender focal points in other ministries, for example finance. We had a lot of private sector companies very interested and INGOs [international NGOs] [as well]. (Interview, September 2018)

During the interview, the Director focused on the localised nature of the KIP Project and associated social media activity.

Then 'Me Too' happened - when 'Me Too' happened, that's the first time we heard the conventional criticism of 'this is an American thing, a European thing, why are you guys talking about it?'. [It was the] first time, we had never heard it before. This is similar to the LGBT [lesbian, gay, bisexual and transgender] rights criticism we get - 'this is American imperialism in a new form'. We had never heard that from KIP. Once 'Me Too' happened, then we started hearing it... it disempowered some of the streams of local narrative by having this rise. Some would say isn't that great that it's happening in the US at the same time, let's build a bridge and make it bigger. No. There's a tipping point where it's disempowering and delegitimising. At some point, it becomes positive again, but right now it's a little murky [...] There's an anti-colonial sense. Pushing back against the hegemony of history that we're still working through. There's a strong history there that's powerful and painful that people are trying to work through. (Interview with Director of the KIP Project, September 2018)

Speaking about the nature and power of collective action, the Director of the KIP Project said:

An eye-opening experience for me in the first month of KIP was, I invited key stakeholders from different groups, for example, a 16-year-old activist, with an entrepreneur, with a large-scale CEO, etc. We held seven focus groups and each one was specifically focused on a different aspect of 
economic empowerment. Observing the conversation, to me, solidified the point that collective mobilising isn't about bringing together the different activists that work on GBV to sit at the same table [...] that's not collective mobilising [...] collective mobilising is people with different world views, with different agendas that have the same core agenda interest in women's empowerment on a specific area or dimension. They may be doing it for different reasons, but the outcome is to improve. And it's challenging. We had people leaving the room because of language - they couldn't agree on the same word to use. (Interview, September 2018)

Despite a resistance to institutional change, civil society in the form of NGOs, academia, and local groups have continued to make positive efforts. Speaking of her own work, the Director of the KIP Project said:

I don't think that change is going to come from national level legislation, at least not for the foreseeable future because we don't have stable mechanisms or stable government and so I believe that partnering with the private sector is the way to go at this point in time with this particular legislation around sexual harassment. (Interview, September 2018)

In the wait for legislators to act on the issue, civil society has been instrumental in breaking the silence around sexual harassment and shaping policy.

\section{Lessons learned}

Collective action by civil society in Lebanon has highlighted the prevalence of sexual harassment and the need for accountability, particularly among refugees and MDW groups. This public realisation is a significant step forward in demanding accountability for victims/survivors. Prior to the global \#MeToo movement, civil society has been pushing towards innovative data collection methods and awareness-building. However, there remains a lack of specific sexual harassment legislation. The two draft laws currently being considered by Parliament present a step forward in achieving legal accountability. However, the legislation has shortcomings in terms of definitional decisions and an understanding of the intersectional nature of sexual harassment. For accountability to become a reality for marginalised groups, holistic legal and social change is necessary.

Accountability has many shapes and forms. In the Lebanese context, the importance of collective action does not just lie in pushing for legislative change and legal accountability; it also lies in the process itself. Collective action is itself a form of accessing support mechanisms for marginalised groups like refugees and MDWs which leads to allies, community, and a form of accountability. For women, the recognition that they were wronged and that their voices are being heard in a supportive 
environment, can be powerful. In addition, collective action and activism around sexual harassment has educated the general public on the unacceptability of sexual harassment and created new avenues of redress which may be parallel and complementary to holding harassers legally accountable.

Given the barriers to accessing justice for women who experience sexual harassment around the world, social change is equally important to legal change. To make a tangible difference in women's daily lives, attitudes towards sexual harassment must change, barriers of accessing justice must be reduced, and efforts among refugee and migrant communities must be amplified (Munshey 2018a). Collective action in Lebanon is itself a form of accountability - it has the effect of building a narrative of delegitimisation and breaking the silence around sexual harassment.

\section{Notes}

* This issue of the IDS Bulletin was prepared as part of Action for Empowerment and Accountability (A4EA), an international research programme exploring social and political action in fragile, conflict, and violent settings. A4EA is a consortium led by IDS and funded with UK aid from the UK government (Foreign, Commonwealth and Development Office - FCDO). The views expressed do not necessarily reflect the official policies of IDS or the UK government.

1 Menaal Munshey, PhD Candidate, Institute of Criminology, University of Cambridge, UK.

2 For more information about the event, see the American University of Beirut website.

3 Burj Barajneh is a Palestinian camp in Beirut with a population of 17,945 refugees and it has a general lack of adequate basic services. For more information, see the United Nations Relief and Works Agency for Palestine Refugees in the Near East (UNRWA) website.

4 Lebanon is not a signatory to the ILO's Decent Work for Domestic Workers Convention (2011), or the United Nations International Convention on the Protection of the Rights of All Migrant Workers and Members of Their Families (1990).

5 A study found that 88 per cent of employers agreed that the employer had the right to keep a worker's passport 'in order to prevent her from escaping'; 31.3 per cent admitted to locking domestic workers in their houses; and 80 per cent said they would not allow workers to take a day off and leave the premises (KAFA 2010).

6 From author's recordings: see endnote 2.

7 From author's recordings: see endnote 2 .

8 A precursor to sexual harassment-focused initiatives was the 'Speak out, don't hide' (takkalami wala takhjali) campaign in 2010 (WEE Portal 2017).

9 See the Adventures of Salwa YouTube channel.

10 See the Adventures of Salwa official website. 
11 Association Najdeh is a feminist, secular NGO focusing on Palestinian women's rights in Lebanon.

12 Harass Tracker categorises sexual harassment ranging across offensive behaviour of a sexual nature using audiovisual tools, oral or verbal harassment, physical acts or gestures with sexual connotation, sexual assault, intimidation, stalking and threats.

13 For more information on the social media campaign, see the KIP Project website.

\section{References}

Amnesty International (2016) 'Lebanon: 'I Want a Safe Place': Refugee Women from Syria Uprooted and Unprotected in Lebanon', Amnesty International (accessed 10 November 2018) An-Nahar (2013) A Campaign to Combat Sexual Harassment [in Arabic] (accessed 10 November 2018)

ARM-Lebanon (2018) About Us, Anti-Racism Movement-Lebanon (accessed 10 November 2018)

AUB (2012) Equity and Title IX Program: Non-Discrimination and Anti-Harassment Initiatives at AUB, American University of Beirut (accessed 10 November 2018)

Barakat, S. (2018) The Cost of Justice: Exploratory Assessment on Women's Access to Justice in Lebanon, Jordan, Egypt and Yemen, Oxfam Policy and Practice Research Report (accessed 10 November 2018)

Charles, L. and Denman, K. (2013) 'Syrian and Palestinian Syrian Refugees in Lebanon: The Plight of Women and Children', Journal of International Women's Studies 14.5: 96-111 (accessed 10 November 2018)

Civil Society Knowledge Centre (2018) Mapping of Incidents of Violence Against Women (accessed 10 November 2018)

Dandan, M. (2017) 'Why is Sexual Harassment in Lebanon Still a Laughing Matter?', Beirut.com City Guide, 6 April (accessed 10 November 2018)

De Stone, R. and Suber, D. (2018) 'Migrant Workers Fighting for Freedom Under Lebanon's Kefala System', Open Democracy (accessed 10 November 2018)

El Helou, M. (2015) 'Legal-agenda.com' (accessed 10 November 2018)

European Union (2017) Combating Sexual Harassment and Abuse in the EU, European Parliament Resolution 2017/2897(RSP) (accessed 24 January 2019)

Ghamroun, S. (2015) 'Who is Afraid of a Female Majority in the Lebanese Judiciary?', The Legal Agenda (accessed 10 November 2018)

Hall, R. (2018a) 'The Secret Networks Saving Lebanon's Migrant Maids from Abuse', The Guardian, 1 August (accessed 10 November 2018)

Hall, R. (2018b) 'Kenyan Domestic Worker Assaulted by Mob in Lebanon Faces Deportation', The Guardian, 5 July (accessed 10 November 2018)

Hassan, S.; El Mir, M. and El Rahi, N. (2017) Attitudes and Practices Towards Sexual Harassment in Beirut, Knowledge is Power (KIP) Project, Beirut: American University of Beirut 
Hejase, H.J. (2015) 'Sexual Harassment in the Workplace: An Exploratory Study from Lebanon', Journal of Management Research 7.1: 107-21

Human Rights Watch (2013) Lebanon: Women Refugees from Syria Harassed, Exploited (accessed 10 November 2018)

Human Rights Watch (2010) Without Protection: How the Lebanese Justice System Fails Migrant Domestic Workers (accessed 10 November 2018)

ILO (2012) Information Guide for Migrant Domestic Workers in Lebanon, Beirut: International Labour Organization (accessed 10 November 2018)

ILO (2010) 'Q\&A About Live-In Domestic Workers in Lebanon', International Labour Organization (accessed 10 November 2018)

Janoubia (2013) Sexual Harassment in the Buses of Dahye: Why Did the Girl Keep Silent? [in Arabic] (accessed 10 November 2018)

KAFA (2010) Servant, Daughter, or Employee? A Pilot Study on the Attitudes of Lebanese Employers Towards Migrant Domestic Workers (accessed 10 November 2018)

Khalidi, A. (2015) Sexual Harassment: A Threat to Human Security in Burj Barajneh Camp?, Association Najdeh (accessed 10 November 2018)

Khneisser, M. (2018) 'Examining Sexual Harassment Draft Laws in Lebanon: Women's Equal Right to Public Space', AUB Policy Brief 2 (accessed 10 November 2018)

LBCl Lebanon (2017) Sexual Assaults Between the Shocking Numbers and Incest [in Arabic] (accessed 10 November 2018)

Legal Agenda (2014) Draft Law on Harassment in the Workplace [in Arabic] (accessed 10 November 2018)

McKernan, B. (2017) 'Lebanese Women Fight Back Against Sexual Harassment with New Campaign', The Independent, 16 August (accessed 10 November 2018)

Moukarbel, N. (2009) Sri Lankan Housemaids in Lebanon: A Case of 'Symbolic Violence' and 'Everyday Forms of Resistance', Amsterdam: Amsterdam University Press

Munshey, M. (2018a) Access to SGBV Protection Services for Syrian and Palestinian Refugees in Lebanon, United Nations University (accessed 10 November 2018)

Munshey, M. (2018b) 'The Tragedy of Plurality: Domestic Violence Law in Lebanon', CEU The Activist (accessed 11 September 2018)

Namour, K. (2017) 'Al-taharoush al-jinsi yourbek al-moushari'n', Legal Agenda (accessed 12 April 2019)

Nasr, N. (2017) Fighting Sexual Harassment in Lebanon: Where Are We Now, and How Far Have We Come?, KIP Project, Beirut: American University of Beirut (accessed 10 April 2019)

$\mathrm{OHCHR}$ (2011) Migrant Domestic Workers in Lebanon are Legally Invisible - UN Expert on Contemporary Forms of Slavery, Office of the High Commissioner for Human Rights (accessed 10 November 2018) 
OHCHR (2009) Creative Solution: A Unified Contract to Protect Domestic Migrant Workers in Lebanon, Office of the High Commissioner for Human Rights (accessed 10 November 2018)

Saida Online (2014) Girls Talk About How They Experienced Sexual Harassment in Lebanon [in Arabic] (accessed 10 November 2018)

United Nations (2008) Secretary-General's Bulletin on Prohibition of Discrimination, Harassment, Including Sexual Harassment, and Abuse of Authority (accessed 10 November 2018)

UN Women, Promundo and CRD (2016) Understanding Masculinities: Results from the International Men and Gender Equality Survey (IMAGES) in Lebanon (accessed 1 September 2018)

WEE Portal (2017) 'Combating Sexual Harassment in Lebanon', Women Economic Empowerment Portal, 14 November (accessed 10 November 2018)

WEE Portal (2013) 'Association Najdeh Launches its Anti-Sexual Harassment Campaign', Women Economic Empowerment Portal, 4 December (accessed 10 November 2018) 